\author{
Dr. Nenad Đurđević, \\ redoviti profesor Pravnog fakulteta Univerziteta u Kragujevcu
}

\title{
UGOVOR O PRUŽANJU USLUGA FITNESA
}

UDK: $347.4: 796.015$

DOI: $10.31141 /$ zrpfs.2021.58.139.55

Pregledni rad

Primljeno: 20. listopada 2020

Fitnes je danas u Evropi najprofitabilnija sportska aktivnost sa skoro 65 miliona korisnika usluga brojnih fitnes centara i klubova u 2019. godini. Fitnes je pojam koji podrazumeva dobro razvijenu fizičku sposobnost, koja je, pak, povezana sa fizičkom pripremljenošću putem fitnes treninga. Usluge u okviru fitnes centara (studija, klubova) danas se pružaju isključivo na osnovu zaključenog ugovora o pružanju usluga fitnesa. U pitanju je neimenovani ugovor koji se različito naziva u pojedinim zemljama. On se u praksi zaključuje skoro isključivo uz korišćenje opštih uslova poslovanja fitnes centra, odnosno putem zaključenja formularnih ugovora unapred pripremljenih od strane fitnes centara. Autor u radu razmatra pitanja zaključenja i pravne prirode tog ugovora.

Ključne reči: fitnes, sport, ugovor o fitnes uslugama, opšti uslovi ugovora, zaštita potrošača

Sport je najraširenija forma moderne telesne kulture koja doprinosi ličnom i društvenom razvoju kroz kreativne aktivnosti i rekreaciju i koja služe zadovoljenju čovekove potrebe za fizičkim vežbanjem radi ličnog fizičkog i mentalnog blagostanja. Odgovarajuća fizička aktivnost je u svim starosnim dobima neophodna za održavanja fiziološkog ,fitnesa“, tj. psihofizičkog kapaciteta koji omogućava da se svakodnevno kretanje i fizički napori obavljaju bez preteranog zamora ili neugodnosti, za regulisanje telesne mase i izbegavanja gojaznosti i za optimalno održavanje visokog nivoa fizioloških procesa, uključujući metabolizam masti i ugljenih hidrata i održavanje odbrambenih sposobnosti organizma protiv infekcija. ${ }^{1}$

\section{TRŽIŠTE USLUGA FITNESA}

Ako biste pitali nekog ljubitelja sporta koji je sport u poslednjoj deceniji najprofitabilniji, velika većina bi rekla „fudbal““. Istina je, međutim, da je, barem u Evropi, najprofitabilnija sportska aktivnost „fitnes“. Koliki je ekonomski i društveni značaj fitnesa kao uslužne delatnosti najbolje se može videti iz godišnjih izveštaja koje poslednjih nekoliko godina redovno objavljuju EuropeActive i Deloitte o stanju

1 Deklaracija o zajedničkim stavovima vezanim za politiku javnog zdravlja Svetske zdravstvene organizacije i Međunarodnog udruženja ża sportsku medicinu (FIMS), doneta 1995. godine na Evropskom kongresu sportske medicine - Granada (Španija). 
tržišta fitnes usluga. Prema izveštaju koji je publikovan početkom 2020. godine, tržište fitnes usluga je nastavilo da raste i u 2019. godini, tako da se broj korisnika usluga fitnesa povećao za 3.8\% dostigavši skoro 65 miliona (u odnosu na 2018. godini to je povećanje za 2.4 miliona novih korisnika - članova), čime je fitnes postao broj 1 sportska aktivnost u Evropi. Ukupna zarada koju su ostvarili fitnes centri (studiji, klubovi) iznosila je 28.2 milijarde evra (uvećanje za $3.1 \%$ u odnosu na 2018. godinu), a broj fitnes objekata (centara, klubova) se povećao za $2 . \%-63.644$. $^{2}$ Najveći prihod je ponovo ostvario David Loyd Leisure (pružalac premium fitnes usluga) - 587 miliona evra, a slede tzv. nisko tarifni fitnes centri Basic-Fit (515 miliona evra), SATS Group (405 miliona evra), Swiss operator Migros Group (367 miliona evra), i RSG Group (365 miliona evra). Jedna od očiglednih tendencija u industriji fitnes usluga je ukrupnjavanje (konsolidacija) pružaoca fitnes usluga, tako da 30 top evropskih fitnes operatora obuhvata 17.2 miliona korisnika (+11.9\%), što je $26.5 \%$ od ukupnog broja članova svih fitnes centara (klubova). Vodeći operator fitnes usluga u Evropi je Basic-Fit sa 2.22 miliona članova, a u top 5 spadaju i RSG Group sa 2.05 miliona članova, Pure Gym a sa 1.35 miliona članova, Clever Fit sa 950.00 članova i The Gym Group sa 794.000 članova. Najveći broj korisnika fitnes usluga je u Nemačkoj - 11.7 miliona, a zatim slede Belika Britanija sa 10.4 miliona, Francuska sa 6.2 miliona, Italija sa 5.5 miliona i Španija sa 5.5 miliona. Prethodni podaci pokazuje da je preko $8.1 \%$ ukupne evropske populacija aktivno u okviru različitih fitnes centara (studija, klubova). ${ }^{3}$ Srazmerno ukupnoj populaciji, najveći broj stanovništva odlazi u fitnes centre u Švedskoj (21.6\%), Norveškoj (21.4\%), Danskoj (18.6\%) i Švajcarskoj (18.6\%). Podaci pokazuju da je broj korisnika fitnes usluga porastao i u poslednjih 10 godina za 72\%. Očekivanja su da će se do 2025. godine fitnesom u Evropi baviti preko 80 miliona ljudi. ${ }^{4}$

Jedno od poslednjih istraživanja je pokazalo da u top 20 evropskih trendova za 2020. godinu spada: 1) Lični trening; 2) Intervalni trening visokog intenziteta (HIIT); 3) Treninga za sniženje telesne težine; 4) Funkcionalni fitnes trening; 5) Lični (personalni) trening u malim grupama; 6) Vežba za mršavljenje; 7) Medicinske (zdravstvene) vežbe: 8) Velnes trening; 9) Boutique fitnes studiji; 10) Kružni (Circuit) trening; 11) Fitnes programi za starije odrasle osobe; 12) Klinička integracija / medicinski fitnes; 13) Grupni trening; 14) Zapošljavanje sertifikovanih fitnes stručnjaka; 15) Licenciranje fitnes profesionalaca; 16) Postrehabilitacione vežbe; 17) Trening sa slobodnim tegovima; 18) Nosiva tehnologija (fitness

\footnotetext{
2 Prema anketi koju je sproveo EuropeActive, 86,7 odsto ispitanika navelo kao razlog za započinjanje fitnes treninga gubitak telesne težine. U SAD je slična situacija - u 2015. ova industrija generisala je prihod od 25,8 milijardi dolara, zahvaljujući mnoštvu korisnika kojima je glavni cilj bio da smršaju. https://opusteno.rs/fitnes-trening-vezbe-f175/zasto-sa-ekspanzijom-fitnes-industrije-raste-i-brojgojaznih-t38776.html.

https://www.europeactive.eu/blog/out-now-european-health-fitness-market-report-2020. Fitnes objekti koji imaju prekom $400 \mathrm{~m} 2$ se uobičajeno nazivaju fitnes centri, a objekti manje površine nose naziv fitnes studiji.

${ }^{4}$ https://www.ispo.com/en/companies/fitness-boom-europe-continues-industry-grows-constantly
} 
tracer, pametni satovi, monitori za srce i dr,, i sa tim „gedžetima“ povezane fitnes aplikacije); 19) Deca i vežbe; 20) Joga. ${ }^{5}$

U svetu je fitnes industrija ubedljivo najrazvijenija u Sjedinjenim Američkim Državama, u kojima je 2015. godine bilo preko 30.000 fitnes klubova sa više od 50 miliona članova. U literaturi se ističe da je tome bitno doprineo „američki model“ razvoja fitnes usluga koga karakterišu sledeći elementi: širok segment korisnika usluga, u koje spadaju i ljudi sa nižim primanjima; visok stepen društvene podrške; široka propaganda zdravih načina života i naglašavanje potrebe za fizičkom aktivnošću; široka cenovna dostupnost; raspored fitnes klubova u svim naseljima, a ne samo u elitnim rejonima; povoljni uslovi kreditiranja početka rada fitnes klubova. ${ }^{6}$

Motivi zašto se odlazi u fitnes centre da bi se tamo treniralo su potpuno različit. neki žele da se osećaju i budu „fit“, neki su usmereni na to da izgube par kilograma a nekima je cilj da se „dobro osećaju“ i „dobro izgledaju“.

\section{FITNES KAO SPORT I KAO USLUGA}

"Fitness" je reč engleskog porekla, koja bi se najjednostavnije mogla prevesti kao „fizička sposobnost“, a potiče od glagola „to fit" - biti u dobroj formi. Termin „fitnes“" suštinski podrazumeva dobro razvijenu fizičku sposobnost. Dobra fizička sposobnost podrazumeva, pak, „fizičku pripremljenost“ putem „fitnes treninga“ (trening za više fitnesa). Fitnes trening je fizički trening (vežbanje) koji služi poboljšanju kondicije, zdravlja i fizičkih performansi vežbača, pri čemu vežbanje treba da prati dobra i zdrava ishrana. Putem fitnes treninga se istovremeno unapređuje snaga, brzina, izdržljivost, fleksibilnost i koordinacija. ${ }^{7}$ Takvi treninzi postoje ne samo u fitnes centrima, fitnes studijima, fitnes klubovima, već i u svim drugim sportskim organizacijama, a mogu se obavljati i u kućnim uslovima. Zbog toga je pojam fitnesa i fitnes treninga teško razgraničiti od drugih sportskih aktivnosti, naročito rekreativnih. ${ }^{8}$

Fitnes u savremenom sportu ima dvostruki status. S jedne strane je posebna sportska grana u okviru koje postoji i razvijen sistem takmičenja, a s druge strane je i rekreativna sportska aktivnost i kao takva deo sportske rekreacije. Na svetskom nivou fitnes kao takmičarsku granu sporta reprezentuje The International

\footnotetext{
5 Alexios Batrakoulis, European survey of fitness trends for 2020, American College of Sports Medicine, Health \& Fitness Journal, November, 2019, str. 29.

6 Марина Владимировна Ефремова, Ольга Владимировна Чкалова и Татьяна Константиновна Бошман, Анализ российского рынка фитнес-услуг, ЭКОНОМИЧЕСКИЙ АНАЛИЗ: теория $u$ практика, бр. 21/2015, str. 29.

7 Gordana Krtinić, Učestalost povreda kod intenzivno fizički aktivnih adolescenata, doktorska disertacija, Medicinski fakultet Univerziteta u Novom Sadu, 2014, str. 20-21.

8 http://www.fitness-trainingsplan, de/fitnesstraining/
} 
Federation of Bodybuilding and Fitness (IFBB) ${ }^{9}$. U Republici Hrvatskoj za fitnes je nadležan Hrvatski bodybuilding savez ${ }^{10}$ a u Republici Srbiji fitnes je kao grana sporta u nadležnosti Saveza Srbije za bodi bilding, fitnes, bodi fitnes i aerobik $(\mathrm{SSBBFBFA})^{11}$, i oba saveza su članice IFBB. U tom pogledu svako lice koje se bavi fitnesom kao takmičarskom sportskom aktivnošću ima status sportiste.

Fitnes se može, međutim, definisati i kao usluga koja se pruža u fitnes centrima, fitnes studijima i sličnim organizacijama (dalje: fitnes centri), u kojima se obezbeđuju uslove za adekvatno sprovođenja fizičkih aktivnosti, odnosno fitnes treninga. U njima vežbači mogu, uz određenu novčanu, najčešće mesečnu, nadoknadu da koriste različite fitnes sprave i uređaje za treniranje (treninzi snage, treninzi uobličavanja mišića, treninzi izdržljivosti, treninzi koordinacije), podržani stručnim kadrom (fitnes treneri, fitnes instruktori). Te treninge često prati usluga podučavanja od stane fitnes trenera, odnosno fitnes instruktora, bilo pojedinačno ili u grupi. U većini savremenih fitnes centara rade, međutim, ne samo fitnes treneri i fitnes instruktori već i sportski medicinari, nutricionisti, fizioterapeuti, kako bi se korisniku usluga fitnes centra obezbedio adekvatni plan treninga i ishrane. $\mathrm{S}$ druge strane, $\mathrm{u}$ velikom broju fitnes centara danas se pored područja za trening nalaze i područja za velnes, saune i masaže, usmerena na osveženje, regeneraciju i opuštanje nakon fitnes treninga.

Drugačija je, međutim, po našem mišljenju, situacija kada se fitnes treninzi obavljaju u okviru sportskih udruženja za fitnes. Kada sportska organizacija (klub, udruženje) stvara uslove da se sportisti njeni članovi bave fitnesom kao sportskom aktivnošću ona to čini u funkciji podrške obavljanju sportskih aktivnosti od strane sportista, pa se kod sportskih organizacija koje su registrovane za fitnes kao granu sporta ili za sportsku rekreaciju kao oblast sporta ne može, po našem mišljenju govoriti o pružanju usluga fitnesa sportistima i drugim članovima sportske organizacije.

9 U okviru IFBB se redovno održava više od 2500 takmičenja na lokalnom nacionalnom, regionalnom, kontinentalnom i svetskom nivou, uključujući i Svetsko prvenstvo u fitnesu. Priznate discipline fitnesa su: Women Fitness, Men Fitness, Women Bodyfitness, Women's Bikini-Fitness, Women's Wellness Fitness, Children Fitness (7-15 godine). https://ifbb.com/.

10 https://www.hbbs.hr/. Ovaj savez je na kraju 2019. godine imao ukupno 27 članica. Prema Statutu HBBS od 13. 09. 2015. godine, članice Saveza mogu biti body building i fitness klubovi, županijski i gradski body building i fitness savezi, Zagrebački body building savez, a i udruge body building i fitness sudaca, licenciranih body building i fitness trenera (čl. 16). Da bi body building i fitness klub postao članicom Saveza mora, između ostalog, da da ima pravo korištenja ili je vlasnik sportskog objekta koji udovoljava propisima sporta, te udovoljava uvjetima za sigurnost i zdravlje sportaša i drugih osoba za bavljenje body buildingom i fitnessom, kao i da ima ugovorene odnose sa osobom koja ima propisanu stručnu spremu odnosno koja je osposobljena za stručne poslove u sportu u skladu sa Zakonom (čl 17). Kao što se može videti, HBBS ne okuplja i ne reguliše delatnost fitnes centara, fitnes studija i drugih fitnes kompanija i preduzetnika. https://www.hbbs.hr/media/Usklaeni_statut_HBBS-a-2015.pdf.

11 Članovi SSBBFBFA mogu biti ne samo savezi i klubovi nego i sve druge organizacije čija je delatnost bodi bilding, fitnes i sportske oblasti - sportska rekreacija (čl. 15. Statuta od 15. 01. 2017. godine, http://bbss.rs/wp-content/uploads/2019/02/statut.pdf ). Savez ima 231 člana. U Republici Srbiji, fitnes ima status i samostalne grane sporta i posebne sportske discipline u okviru oblasti sporta - sportska rekreacija. 


\section{ZAKLJUČENJE UGOVORA O PRUŽANJU USLUGA FITNESA}

Savremena komercijalizacija sporta dovela je do toga da je danas postojanje ugovora između sportista i sportskih klubova pravilo a ne izuzetak. Međutim, najveći broj sportskih organizacija kako u Hrvatskoj i Srbiji tako i u svetu u pravnom je statusu udruženja (građana). Shodno tome, sportista, načelno, ne mora da bi se bavio sportskim aktivnostima u sportskom udruženju čiji je član da ima sa njim zaključen bilo kakav ugovor. Šta više, to je suprotno izvornim ciljevima stvaranje bilo koje sportske organizacije kao udruženja. Zajednički cilj u oblasti sporta zbog koga su se neka lica udružila upravo leži u bavljenju udruženih lica sportskim aktivnostima (sportisti) i sportskim delatnostima (treneri, službena lica i dr.). Zbog toga, članovi sportskog udruženja ne bi trebali, po pravilu, ni da zaključuju nikakav ugovor sa udruženjem jer upravo oni sami čine udruženje. Dovoljno je da su se „učlanili“ u sportsko udruženje.

Drugačije je kada su u pitanju fitnes centri. Usluge u okviru fitnes centara se pružaju isključivo na osnovu zaključenje ugovora o pružanju usluga fitnesa. S obzirom na savremeni značaj tržišta fitnes usluga i broj korisnika usluga, ugovor o pružanju usluga fitnesa ima veliki praktični pravni značaj. Koliko je, međutim, nama poznato, ni u Republici Hrvatskoj ni u Republici Srbiji ovom ugovoru nije u pravnoj literaturi poklonjena odgovarajuća pažnja, što ne čudi imajući u vidu činjenicu da sudskih sporova u vezi zaključenja i ispunjenja ovog ugovora skoro da nema. Do duše, to je u suprotnosti sa kako brojem organizacija koje pružaju usluge fitnesa tako i brojem korisnika. Na primer, u Republici Srbiji ima preko 2500 organizacija i preduzetnika registrovanih za delatnost „fitnes klubova“, sa oko pola miliona korisnika usluga, odnosno članova. Imajući to u vidu, cilj ovog rada je da ukaže na osnovne karakteristike zaključenja ovih ugovora i na njihovu pravnu prirodu. Razmatranje brojnih drugih pitanja, posebno onih vezanih za nedopuštene ugovorne odredbe i za mogućnost prevremenog jednostranog raskida ugovora, zahtevalo bi obimniji studiju.

Ugovor o pružanju usluga fitnesa je ugovor koji se u praksi zove različito: ugovor o treniranju, ugovor o fitnesu, ugovor o članstvu u fitnes centru (klubu) i dr. (Fitnessvertrag, Fitness Contract, Gym Membership Contract, Membership Agreement, Trening Contract). Reč je o neimenovanom, obostrano obavezujućem, komutativnom, teretnom (naplatnom), kauzalnom i neformalnom ugovoru, koji je najčešće i trajni ugovor i ugovor koji se zaključuje intuitu personae.

Osnovna sadržina takvog ugovora je obaveza fitnes centra da stvori uslove i omogući korisniku usluga (klijentu, članu, korisniku) da posećuje i koristi, u radno vreme fitnes centra, sve sadržaje - servise fitnes centra (objekte - uključujući i svlačionice i tuš kabine, sprave, uređaje, programe treninga i druge usluge) koje služe fizičkom vežbanju (fitnes treningu), i obaveza korisnika da, po pravilu, plaća mesečnu nadoknadu za tu uslugu tokom ugovorenog vremena. U praksi je uobičajeno i da kada se prvi put zaključuje ugovor da se prilikom zaključenja ugovora plaća tzv. upisnina, kao jednokratna naknada. Poslednjih godina, međutim, uz navedene 
„osnovne usluge“ ide i čitav niz drugih usluga, pri čemu su neke deo „osnovnog paketa" a neke se posebno i dodatno plaćaju (personalni trening, grupni trening, korišćenje solarijuma, korišćenje saune, masaža, fizioterapeut, kursevi aerobika ili neke druge sportske aktivnosti, i dr.). Uobičajeno je da fitnes centri u svojoj ponudi imaju unapred definisane pakete usluga (članske statuse) koje „klijent“ može da bira. Tako, na primer, jedan startni paket sadrži: pristup fitnes centru (korišćenje sprava i uređaja, svlačionica i sl.), neograničen broj termina, pristup grupnim treninzima, merenje i startni plan vežbi, savetovanje sa fitnes trenerom - instruktorom. U ugovorne obaveze fitnes centra spada i dužnost da sve sprave i uređaji (oprema) održava i servisira u ispravnom stanju i da se korisnik obavesti o mogućim rizicima i mogućim oštećenjima zdravlja prilikom fitnes treninga, posebno na određenim spravama $^{12}$. S druge strane, i korisnik ugovorom, najčešće, preuzima veći broj sporednih obaveza: da se pridržava radnog vremena fitnes centra, da opremu fitnes centra koristi u skladu sa namenom, da održava prostorije urednim, da se za vreme treninga pristojno ponaša, da nosi odgovarajuću sportsku opremu, da istovremeno koriste samo jednu spravu (radno mesto) i za primereno vreme, da ne unose i koristi hranu i alkohol u prostoru za trening, da ne puši, da ne koristi drogu ili zabranjena stimulativna sredstva, i dr.

Ugovor o pružanju fitnes usluga je, po pravilu, trajni ugovor, odnosno njim se stvara trajni obligacioni odnos. Ugovor se zaključuje ili na određeno vreme ili za određeni program. Uobičajeni su oročeni ugovori, koji se automatski produžava ukoliko se prethodno blagovremeno ne raskinu (otkažu). Izuzeci su mogući, ali su u odnosu na ukupan broj ugovora zanemarljivi i tiču se uglavnom ugovaranja određenog broja personalnih fitnes treninga. U uporednom pravu su dva pitanja sporna u vezi trajanja ugovornih obaveza, i tiču se maksimalno dopuštenog roka za zaključenje ugovora i mogućnosti jednostranog raskida ugovora. Ta dva pitanja su u praksi često i neposredno povezana na taj način da se zaključuje ugovor na neodređeno vreme, ali se korisnik obavezuje da neće raskinuti ugovor za određeno vreme.

U nemačkoj sudskoj praksi je prihvaćeno da ugovor o pružanju usluga fitnesa (fitnes ugovor) može da se zaključiti do 24 meseca. Tako je, na primer, Landesgericht Menhengladbah u svojoj presudi od 30.05.2003 - 2 S 22/03 utvrdio da početni ugovorni rok od 24 meseca ne predstavlja neprimereno škođenje druge ugovorne strane ako vlasnik fitnes studija svojim klijentima na početku ugovora omogući izbor između nekoliko rokova trajanja ugovora, uzimajući u obzir njegove fizičke i ekonomske okolnosti. U konkretnom slučaju klijent je imao izbor između „probne pretplate“ bez određenog roka, ,kratke pretplate“ od 12 meseci, ,, normalne pretplate“ od 18 meseci i „,fitnes pretplate“ od 24 meseca. Sud nije našao ni da je problematično to što je fitnes studio priznavao nižu ceni što je duži ugovorni period, želeći da stimuliše klijente da zaključe dugoročni ugovor. Po mišljenju suda, takva

12 Mnogi fitnes centri u svoje opšte uslove poslovanja i ugovore unose odredbe kojima celokupni rizik korišćenja usluga i opreme fitnes centra prebacuju na korisnika (pozivanje na postupanje na sopstveni rizik). 
praksa omogućava fitnes studiju da stvori osnovu za kalkulaciju kupovine nove opreme ili za angažovanje dodatnog osoblja. ${ }^{13}$ Ugovorni rok koji bi bio duži od 24 meseca je nedopušten jer se prema stanovištu nemačkih sudova time neprimereno oštećuje korisnik usluga, suprotno par. 307. st. 1. reč. 1 Građanskog zakonika (Bürgerliches Gesetzbuch - BGB). Prema stanovištu Amstgericht Spandau, iz presude 10 C 193/09 od 02. 12. 2009. godine, kod fitnes ugovora postoje značajna ekonomska i lična očekivanja klijenata, zbog čega je primeren ugovoreni rok koji nije duži od dve godine. ${ }^{14}$ Da je rok od 24 meseca dopušten, stanovište je i Saveznog vrhovnog suda Nemačke (BGH), zauzeto u presudi od 8. februara 2012 - XII ZR $42 / 10 .^{15}$

Prema stanovištu nemačkih sudova, kako se fitnes ugovorom stvara trajni obligacioni odnos ${ }^{16}$ to svaka ugovora strana, u skladu sa uobičajenom sudskom praksom o raskidanju trajnih ugovora ${ }^{17}$, načelno ima pravo na vanredno (prevremeno) raskidanja ugovora u slučaju postojanja značajnog razloga (osnova), u skladu sa par. 314. BGB. To pravo se, načelno, ugovorom ne može ni isključiti. ${ }^{18}$ Kada takav razlog (osnov) postoji, u sudskoj praksi je sporno. Primera radi, ne predstavlja dovoljni osnov za jednostrani prevremeni (vanredni) raskid ugovora bolest za koju je korisnik znao. ${ }^{19}$ Međutim, na korisniku je da snosi rizik da više nije u mogućnosti da koristi uslugu koju pruža fitnes centar zbog promene njegovih ličnih okolnosti. Drugačije važi samo ako se ne može opravdano očekivati da klijent dalje koristi usluge fitnes centra iz razloga na koje ne može uticati, kao što je, na primer, trudnoća. ${ }^{20}$

Jedno od značajnijih pitanja kojim se bavio i austrijski Vrhovni sud (Der Oberste Gerichtshof - OGH) bilo je vezano za rokove raskida ugovora kod vremenski

13 https://www.kostenlose-urteile.de/LG-Moenchengladbach_2-S-2203_Erstvertragslaufzeit-von-24 -Monate-fuer-Fitnessstudio-bei-Moeglichkeit-zur-Wahl-der-Vertragslaufzeit-zulaessig.news20442.htm

14 https://www .rab-friedrich-ramm.de/beitrag19_Sportstudiovertrag.html

15 https://dejure.org/dienste/vernetzung/rechtsprechung?Gericht=BGH\&Datum=02.08.2012\&Akten zeichen=XII\%20ZR\%2042/10

16 Amtsgericht Brandenburg, Urteil Az: 31 C 204/15 vom 18. 04. 2016, https://www.ra-kotz.de/ fitnessstudiovertrag-rechtsnatur.htm

17 Videti, BGH, Urteil vom 07.03.2013, Az.: III ZR 231/12, https://dejure.org/dienste/vernetzung/rech tsprechung?Gericht=BGH\&Datum=07.03.2013\&Aktenzeichen=III\%20ZR\%20231\%2F12; BGH, Urteil vom 08.02.2012, Az.: XII ZR 42/10, https://juris.bundesgerichtshof.de/cgi-bin/rechtsprechung/document. py?Gericht=bgh\&Art=en\&az=XII\%20ZR\%2042/10\&nr=59681; AG Brandenburg an der Havel, Urteil vom 15.10.2015, Az.: 34 C 5/15, https://dejure.org/dienste/vernetzung/rechtsprechung?Gericht=AG\%20 Brandenburg \&Datum $=15.10 .2015 \& A k t e n z e i c h e n=34 \% 20 \mathrm{C} \% 205 \% 2 \mathrm{~F} 15$. U pitanju je sudska praksa u vezi primene $\S 626$ Abs. $1, \S 543$ und $\S 314$ Abs. 1 BGB.

18 BGH, Urteil vom 08.02.2012, Az.: XII ZR 42/10; AG Brandenburg an der Havel, Urteil vom 15.10.2015, Az.: 34 C 5/15

19 Amtsgericht München, Urteil vom 13.10.2011, Aktenzeichen 213 C 22567/11, https://dejure. org/dienste/vernetzung/rechtsprechung?Gericht=AG\%20M\%FCnchen\&Datum=13.10.2011\&Aktenz eichen=213\%20C\%2022567/11; Amtsgericht Hamburg, Urteil vom 05.02.1998, Aktenzeichen 20 b C 367/97, https://dejure.org/dienste/vernetzung/rechtsprechung?Gericht=AG\%20Hamburg\&Datum=05.02. 1998\&Aktenzeichen=20b\%20C\%20367\%2F97. O razlozima koji mogu biti osnov za prevremeni raskid ugovora više videti: https://www.rab-friedrich-ramm.de/beitrag19_Sportstudiovertrag.html

20 BGH, Urteil vom 4. 05. 2016. - KSII ZR 62/15, https://dejure.org/dienste/vernetzung/rechtsprech ung?Gericht=BGH\&Datum=04.05.2016\&Aktenzeichen=XII\%20ZR\%2062/15 
neoročenih ugovora o pružanju usluga fitnesa (članskih ugovor). U opštim uslovima jedne fitnes kompanije, koja je korisnicima stavljala na raspolaganje uređaje za vežbanje snage koji su se mogli koristiti isključivo uz prisustvo i vodstvo trenera do dva puta nedeljno, navedena je odredba da je raskid ugovora (koji se zaključuje na neodređeno vreme) moguć tek nakon isteka jedne godine, a nakon toga po isteku pola godine. Raskid trebao je da bude izjavljen pismeno (ne može mejlom ili faksom) iz dvomesečni raskidni rok. OGH je u presudi $5 \mathrm{Ob} 205 / 13 \mathrm{~b}$ od 13 . marta $2014 .{ }^{21}$ godine zaključio da takva klauzula nije nedopuštena. Prema stanovištu OGH, potrošači su zaštićeni odredbama par. 6. st. 1. tač. 1 Konsumentenschutz Gesetz $(\mathrm{KSchG})^{22}$ i par 879. Allgemeines bürgerliches Gesetzbuch (AGBG) od neprimereno dugog ugovornog vezivanja. Kod trajnih ugovornih odnosa procenjivanje da li su odredbe koje utiču na dužinu ugovornog vezivanje neprimerene vrši se u pojedinačnom slučaju na osnovu ocene suprotstavljenih interesa ugovornih strana. Primerenost roka određuje se prema vrsti posla i prema rokovima koji se uobičajeno ugovaraju od strane savesnih ugovornih strana. Duže ugovorno vezivanje potrošača može, na primer, biti opravdano u slučaju investicionih ulaganja druge ugovorne strane i sa time povezanih privrednih rizika. Kompanija koja u trajnom ugovornom odnosu finansira ugovorne činidbe i time snosi veći ekonomski rizik, mora svog ugovornog partnera vezati na duže vreme kako bi mogla da ograniči rizike putem opravdane kalkulacije. U konkretnom slučaju je ugovorno vezivanje potrošača (korisnika fitnes usluga) od najmanje godinu dana bilo opravdano, imajući u vidu investicije i troškove obezbeđenja potrebnog broja trenera kako bi se svakom korisniku omogućilo korišćenje ugovorenog vremena treniranja. Samim tim nisu neprimerene ni odredbe opštih uslova poslovanja o rokovima za raskid ugovora.

Austrijski OGH se u presudi 9 Ob 69/1 ld od 29. 05. 2012. ${ }^{23}$ godine bavio i pitanjem da li je kod ugovora koji je zaključen na neodređeno vreme dopuštena klauzula opštih uslova poslovanja prema kojoj korisnik usluga može da bira da li će se odreći mogućnosti da raskine ugovor za prvih 12, 24 ili 36 meseci, a u zavisnosti od izbora određivao se i mesečni iznos naknade (što je duži rok odricanja to je naknada niža - za 12 meseci 90 evra, za 24 meseca 80 evra i za 36 meseci 75 evra mesečno). Prema stanovištu OGH, čak i uz uzimanje u obzir povoljnije cenovne tarife u slučaju dužeg ugovornog vezivanja, ne može se pronaći dovoljan osnov koji bi mogao opravdani rok važenja ugovora od 24 i 36 meseci. Zbog toga je klauzula opštih uslova poslovanja koja predviđa odricanje od prava na raskid ugovora 24 i 36 meseci neprimerena u smislu par. 6. st. 1 . broj 1 KSchG.

Iz prethodnog izlaganja može se videti različit stav austrijske i nemačke sudske prakse o maksimalno dozvoljenom, odnosno primerenom roku na koji se može

21 https://rdb.manz.at/document/ris.just.JJT_20140313_OGH0002_0050OB00205_13B0000_000

22 U par. 6. KSchG navedene su brojne ugovorne odredbe koje nisu obavezujuće za potrošača i ne mogu se obavezujuće ugovoriti. Tu posebno spadaju ugovorne odredbe koje potrošača vezuju za određeni ugovor neprimereno dugo ili za nedovoljno određen rok.

23 https://www.ris.bka.gv.at/Dokument.wxe?Abfrage=Justiz\&Dokumentnummer=JJT_20120529_ OGH0002_0090OB00069_11D0000_000 
zaključiti ugovor o pružanju usluga fitnesa. Dok austrijski pravnici smatraju da je to 12 meseci, nemački su mišljenje da je to 24 meseca.

Ugovor o pružanju usluga fitnesa se može zaključiti pismeno ili usmeno, pa čak i putem konkludentnih radnji. Ponuda i prihvat ponude moraju se, međutim, odnositi najmanje na bitne elemente ugovora. Prema stanovištu nemačkih sudova, tu spada određenje ugovornih strana, mesta za trening i roka trajanja ugovora, pri čemu ti elementi moraju biti u dovoljnoj meri određeni, uzimajući u obzir i volju ugovornih strana usmerenu na zaključenje ugovora, kako bi se mogla spoznati sadržina ugovora. ${ }^{24}$

Za punovažno zaključenje ugovora o pružanju usluga fitnesa potrebno je da su ispunjeni svi uslovi kao i za punovažnost bilo kog drugog obligacionog ugovora, u odnosu na predmet i osnov ugovora kao i volju ugovornih strana. To podrazumeva i da ne postoje manje volje ugovarača. Tako je, na primer, Amtsgericht Münster, u svojoj presudi od 8.06.2014 - 271 C 30721/13, utvrdio da se ugovor može pobijati zbog postojanja zablude korisnika, koji je potpisao ugovor bez čitanja jer je zaboravio naočare a pokazalo se da ugovor ima drugačiju sadržinu od očekivane i željene. Slučaj se ticao situaciju u kojoj je sedamdeset godišnja gospođa zaključila ugovor sa fitnes studijom nakon što je dobila reklamni flajer na kome je bilo navedeno „Probajte nas! Dve nedelje 19,90 evra - poslednji startni termin 28. 2. 2013.“ Kako joj je početkom 2013. godine lekar preporučio vežbe zbog operacije leđa, odlučila je da poseti fitnes studio, što je i učinila pre isteka perioda akcije, noseći sa sobom flajer, na koji se i pozvala. Pošto je zaboravila da ponese naočare nije mogla da pročita ugovor koji joj je ponuđen od strane službenika fitnes centra, što je i rekla tom službeniku. Na više puta ponovljeno pitanje, službenik fitnes centra je potvrdio da ugovor odgovara ponudi koja je bila navedena u flajeru. Gospođa je međutim potpisala ugovor na 64 nedeljni bazični paket, koji je podrazumevao obavezivanje na plaćanje 16 evra nedeljno i startni paket od 49 evra. Nakon što se gospođa došla kući, pročitala je ugovor i primetila je da je bila u zabludi, pa je zatražila od fitnes studija raskid ugovora zbog prevare. Fitnes studio je to odbio i zahtevao je isplatu svih ugovorenih iznosa u ukupnom iznosu od 1.130 evra. Kako klijent nije hteo da plati, fitnes studio je podneo tužbu sudu. Amstgericht Münster je, međutim, zaključio da tužena gospođa nije dužna da plati zahtevani iznos naknade jer je zaključila ugovor u zabludi. Sud je pošao od prakse Saveznog vrhovnog suda Nemačke (BGH) još iz 1994. godine prema kojoj onaj ko potpiše ugovornu ispravu bez čitanja može pobijati ugovor zbog zablude ukoliko je o sadržini ugovora opravdano imao netačnu predstavu. Sud ipak nije prihvatio postojanje prevare od strane fitnes centra. ${ }^{25}$

Jedna od čestih situacija je i da se ugovor o pružanju usluga fitnesa zaključuje nakon što korisnik „odradi“" besplatni, reklamni, probni trening. U nemačkoj sudskoj praksi se postavilo pitanje da li se takvi ugovori mogu raskinuti (opozvati)

24 Amtsgericht Brandenburg, Urteil Az: 31 C 204/15 vom 18. 04. 2016, https://www.ra-kotz.de/ fitnessstudiovertrag-rechtsnatur.htm

25 https://www.kostenlose-urteile.de/AG-Muenster_271-C-3072113_Brille-vergessen-UngelesenerVertrag-mit-anderem-Inhalt-als-gedacht-kann-wirksam-angefochten-werden.news 19089.htm 
pozivanjem na pravila o potrošačkim ugovorima, u smislu par. 312. br. 2. BGB. Prema par. 312. BGB, potrošač ima pravo da odustane od ugovora ukoliko ga je zaključio na svom radnom mestu ili stanu, na javnom mestu (ulici, železničkoj stanici) ili u okviru događaja u slobodnom vremenu (npr. odlazak na kafu). Kod takvih situacija radi se o izvesnoj „,neočekivanoj situaciji“. Amtsgericht München je, u svojoj presudi od 25. 10. 2012 - 223 C 12655/12, na ovo pitanje dao negativan odgovor. U konkretnom slučaju, zainteresovani gospodin je obratio pažnju na određeni fitnes studio jer je dobio reklamnu ponudu za besplatni probni trening. Otišao je do fitnes studija i posle treninga je potpisao ugovor na period od 12 meseci, sa mogućnošću produženja. Kada je sledeći put došao, pažljivije je procenio prostorije fitnes studija i mogućnosti za trening i zaključio je da ne želi da bude član takvog fitnes studija. Zbog toga je sledećeg dana raskinuo ugovor. Fitnes studio je zatražio plaćanje ugovorenog iznosa od 599 evra za ugovorni period od 12 meseci. Klijent je odbio da plati, pa je fitnes studio podneo tužbu. Amtsgericht München je zaključio da tuženi klijent nema pravo na opoziv ugovora (Widerrufsrechts) jer se kod fitnes ugovora ne radi ni o ugovoru zaključenom na kućnom pragu ni ugovoru zaključenom u slobodnom vremenu. Prema stanovištu suda, nije ni za koga iznenađujuće da fitnes studio (centar) koristi probne treninge u reklamne svrhe, kako bi pridobio nove članove. Kada neko zaključi ugovor sa fitnes studiom nakon reklamnog probnog treninga, ne može se pozivati da je bio izložen iznenađenjima ili prevari. Ko zaključi ugovor a da se prethodno ne informiše tačno o svim okolnostima, postupa na sopstvenu odgovornost i vezan je ugovorom. ${ }^{26}$ Međutim, u jednom drugom slučaju je Landgericht Koblenz zaključio da je između klijenta i fitnes studija zaključen ugovor na kućnom pragu, shodno par. 312. st. 1. reč. 1, br. 2 BGB, u situaciji kada je klijent u svom poštanskom sandučetu našao flajer sa natpisom da je „,dobio“ probni trening, pa je prilikom probnog treninga zaključio ugovor. ${ }^{27}$ Po mišljenju ovog suda, kod obavljanja „dobijenog“" probnog treninga u fitnes studio radi se o događaju u slobodnom vremenu koji je organizovan od trgovca, i to važi i tada kada je termin za sprovođenje treninga određen na inicijativu klijenta. U skladu sa tim, klijent (korisnik usluga) ima pravo da opozove ugovor u roku od 14 dana (par. 355. st. 2. BGB), od dana zaključenja ugovora, ako drugačije nije ugovorom određeno. Opozivanje ne mora da ima bilo kakvo obrazloženje (par. 355. st. 1. BGB).

Od reklamnih probnih treninga treba razlikovati treninge u ,probnom periodu“, koji se posebno ugovaraju za određeno vreme (najčešće mesec dana), a u kom periodu se ugovor može jednostrano raskinuti (otkazati). Takav način zaključenja ugovora se preporučuje, naročito neiskusnim korisnicima, jer za „Zadovoljstvo“ pruženim uslugama u fitnes centru često nije odlučujuće kakve su sprave i uređaji, već je bitnije kakva je ,atmosfera“ u prostorijama fitnes centra i među vežbačima.

26 https://www.kostenlose-urteile.de/AG-Muenchen_223-C-1265512_Bei-Vertragsabschluss-nachProbetraining-im-Fitnessstudio-besteht-kein-Widerrufsrecht.news15168.htm

27 Urteil vom 02.10.2007, Aktenzeichen 6 S 19/07, http://www.landesrecht.rlp.de/jportal/portal/ t/7qe/page/bsrlpprod.psml?pid=Dokumentanzeige \&showdoccase=1\&doc.id=KORE241662007\&doc . part $=\mathrm{L}$ 
Pošto većina fitnes centara ne žele da zaključuju ugovore „na probu“, druga mogućnost je da se uzme tzv. dnevna karta. naravno, ako i za to postoji mogućnost.

Fitnes centar i korisnik usluga fitnesa zaključuju u praksi ugovor o pružanju usluga fitnesa skoro isključivo korišćenjem opštih uslova poslovanja fitnes centra, odnosno potpisivanjem tipskog formulara ugovora koji je pripremio fitnes centar. Prava i obaveze ugovornih strana su tim formularima detaljno regulisana za najveći broj pitanja, i u suštini ugovornicima ostaje da individualno odrede još samo cenu usluga, način isplate i vreme trajanja ugovora. Prema stanovištu nemačke sudske prakse, tipski ugovori u sportu su ugovori koji se zaključuju na osnovu opštih uslova poslovanja, u smislu par. 305 . BGB..$^{28}$

Pravnu važnost opšti uslovi fitnes centra dobijaju samo od slučaja do slučaja, tako što ih druga ugovorna strana prihvata, odnosno saglašava se sa njihovim uvršćenjem u zaključeni ugovor (tzv. formularni ugovor). ${ }^{29}$ Opšti uslovi postaju sadržina ugovora i obavezuju drugu strani samo ako ako su joj bili poznati ili morali biti poznati u trenutku zaključenja ugovora, odnosno ukoliko je imala mogućnost da se na očekivani, uobičajeni i razumljiv način (uzimajući u obzir očekivanja prosečnog klijenta) upozna sa sadržinom opštih uslova. Tek prihvatanjem druge strane, opšti uslovi formalno postaju lex contactus, i to samo za ugovorne strane i samo na osnovu njihove saglasnosti. ${ }^{30}$

Kako izgledaju neki opšti uslovi fitnes centra u Hrvatskoj, kao primer mogu poslužiti detaljni (64 člana) Opći uslovi poslovanja OrlandoFit trgovačkog društva iz Zagreba ,za djelatnosti poboljšanja fizičke kondicije, ostale sportske djelatnosti i drugo“", koje ima dva fitnes centra u Zagrebu. U skladu sa tim Općim uslovima poslovanja, između OrlandoFit (Ugovaratelj) i Korisnika se sklapa formularni Ugovor o članstvu kojim se „OrlandoFit obvezuje omogućiti korištenje fitness centra u vlasništvu ili zakupu OrlandoFit-a (dalje: fitness centri), opreme u fitness centrima, programa treninga u fitness centrima i druge svoje usluge Korisniku, sve u rokovima i pod uvjetima kako određeno ovim Općim uvjetima te drugim javno objavljenim pravilima OrlandoFit-a, a Ugovaratelj se obvezuje plaćati

28 Videti npr. presudu Arbeitsgericht Ulm, od 14.11.2008, 3 Ca 244/08, www.jusmeum.de/ rechtsprechung/urteil/arbg_ulm/805bed22b9e5d6630f70edb45dd7e73a320a44d28eb8bac15122d61b49f b3ddf?page $=1$

29 Međutim, korisnik usluga fitnesa je često prinuđen da prihvati čak i one odredbe opštih uslova koje su za njega nepravične, koje ga lišavaju određenih prava ili ga u najmanju ruku ograničavaju. To, razume se, sa svoje strane nameće potrebu da mu se, pogotovu što najčešće i nije u situaciji da sagleda sav domašaj pojedinih opštih uslova, pruži zaštite od mogućih zloupotreba. Zaštita od nepravičnih opštih uslova poslovanja smatra se sastavnim delom zaštite potrošača (Erik Jayme, Allgemeine Geschaeftsbedingungen und internationales Privatrecht, Zeitschrift fuer das gesamte Handelsrecht und Wirtschaftsrecht, br. 2 , 1978, str. 106).

30 Formularni ugovori mogu se zaključiti ne samo izričito nego i prećutno. Za punovažnost opštih uslova nije od značaja u kojem obliku se oni pojavljuju: formularni ugovor sadrži odštampane kompletne uslove; opšti uslovi su odštampani na poleđini ugovora ili u vidu posebne brošure, a ugovorna isprava se na njih poziva; opšti uslovi su priloženi ponudi za zaključenje ugovora; primena opštih uslova je uobičajena u odnosnoj privrednoj grani, a njihov tekst je objavljen na uobičajen način. Za punovažnost opštih uslova nije od značaja ni da li je korisnik njih sam sastavio ili se u svom poslovanju pridržava opštih uslova koje je pripremila neka druga organizacija, komora ili poslovna zajednica (Ivica Jankovec, Ugovori u privredi, Beograd, 1987, str. 92). 
članarinu i upisninu OrlandoFit-u, u iznosu i rokovima kako određeno ovim Općim uvjetima, Cjenikom i drugim pravilima OrlandoFit-a. “31 Obaveze na plaćanja članarine i upisnine ne ovise o korišćenju usluga od strane Korisnika, a svoje pravo korišćenja usluga OrlandoFita-a Korisnik ne može ustupiti ili preneti drugoj osobi, osim uz pisano odobrenje OrlandoFit-a. Članarina je naknada za korišćenje usluge i opreme OrlandoFit-a, te predstavlja iznos koji Korisnik plaća na način i u rokovima odabranim u Ugovoru o članstvu. Nakon uplate upisnine i sklapanja Ugovora o članstvu, Korisnik dobija člansku iskaznicu, koja glasi na ime Korisnika i neprenosiva je, a da bi se koristile usluge fitnes centra članska iskaznica se mora predočiti prilikom svake posete fitnes centru. ${ }^{32}$ Ugovor se može sklopiti na vreme od mesec dana (Mesečni ugovor), 12 meseci (Godišnji ugovor) ili 13 meseci (Produženi godišnji ugovor).

\subsection{Pravna priroda ugovora}

Kao i u drugim oblasti života gde se u jednom te istom činjeničnom događaju susreću sastavni elementi više vrsta ugovora, tako se i kod ugovora o pružanju usluga fitnesa postavilo pitanje kako takvo preplitanje utiče na pravnu prirodu ovog ugovora.

Ogromna većina austrijskih pravnika smatra da je, u svojoj osnovnoj varijanti, reč o mešovitom ugovoru sa elementima ugovora o zakupu i elementima ugovora o službi. Prema stanovištu austrijskog Vrhovnog suda (OGH), bitna sadržina ugovora se sastoji u stavljanju na raspolaganje (korišćenje) sportskih i fitnes uređaja, čime ugovor o pružanju usluga fitnesa u najvećoj meri ima elemente ugovora o zakupu. Stvaranje, opremanje i održavanje određenog prostora za organizovani fitnes trening nema elemente ugovora o delu, jer se zaključenjem ugovora ne duguje određeni rezultat, već samo rad. U situaciji kada se ugovorom obuhvata i korektivna ili savetodavna usluga fitnes trenera, tada ugovor sadrži elemente ugovora o službi. Međutim, ti elementi imaju sporednu ulogu. ${ }^{33}$

Nemački pravnici nemaju jedinstveno mišljenje o tome kakva je pravna priroda ugovora o pružanju usluga fitnesa (Fitness Vertrag - fitnes ugovor). Celokupna rasprava potiče iz shvatanja da kod savremenih fitnes centara korisnici (klijenti) imaju izbor da li žele da se bave tzv. grupnim treningom i/ili tzv. treningom na uređajima (spravama). Jedinstveno je stanovište da su kod ugovora koji su usmereni na obezbeđenje grupnih treninga, koji se uvek nalaze pod vođstvom trenera, preovlađujući elementi ugovora o službi, pa se na ugovor primenjuju odredbe par.

31 Videti, https://www.orlandofit.hr/o-nama/orlandofit-pravilnik/

32 Iako se govori o „članskom ugovoru, „članarini“, „članskoj iskaznici“, iz Općih uslova poslovanja i samog formularnog ugovora je više nego jasno da se tu ne radi o učanjenju u OrlandoFit niti o članarini koja se plaća od članova sportskih udruga (udruženja). U pitanju je klasični ugovor o uslugama i o plaćanju naknade za pružene usluge. Terminologija koju koristi OrlandoFit nije neuobičajena u fitnes industriji, ali tu se primenjuje opšte pravilo da pravnu prirodu ugovora ne određuje naslov ugovora već njegova sadržina.

33 Videti ranije navedene presude, OGH 9 Ob 69/11d od 29.5.2012 i OGH 5 Ob 205/13b od 13.3.2014. 
611. BGB. Izabere li korisnik grupni trening, onda se elementi prepuštanja korišćenja svode samo na omogućavanje prostora za trening. Međutim, sporna je pravna priroda ugovora u slučaju kada je korisnik izabrao da sam trenira na uređajima koji se nalaze u prostorijama fitnes centra, što je prema stanovištu nemačkih pravnika osnovni oblik ugovora o fitnesu. Kod treninga na uređajima, fitnes centar duguje korisniku da mu prepusti na korišćenje uređaje za fitnes u određenom prostoru za trening. Prema vladajućem mišljenju, koje je prihvaćeno i u sudskoj praksi ${ }^{34}$, ugovor o fitnesu koji za predmet ima treniranje na uređajima je mešoviti ugovor koji se sastoji od kombinaciji različitih, pravno nesamostalnih tipova ugovora koji se udružuju u jedinstven ugovor kod koga je ipak težište na elementima prepuštanja korišćenja (upotrebe), pa samim tim na njega treba primeniti i pravila o ugovoru o zakupu, shodno par. 535. BGB. Mogućnost da se korisnik posavetuje sa fitnes studijom ili njegovim nameštenicima o korišćenju uređaja kao i obaveza fitnes centra da nadzire trening na uređajima i interveniše ukoliko dođe do ugrožavanja samog korisnika ili drugih sportista su samo sporedne obaveze, koje prate glavnu. ${ }^{35}$ Ipak, deo sudske prakse i pravne literature smatra da su i kod fitnes ugovora kod kojih je težište na treningu na spravama obaveze fitnes centra na nadzire i savetuje korisnika toliko bitne da su odredbe par. 611 BGB o ugovoru o službi barem podjednako važne kao i one iz par. 535. BGB. ${ }^{36}$

Manjina nemačkih pravnika smatra da je ovakva pravna konstrukcija čista fikcija, koja ne odgovara pravoj volji ugovornih strana, i zasniva se na tzv. pojmovnom metodu određivanja pravne prirode ugovora, prema kome se elementi nekog ugovora određuju prema „,pojmu“ ugovora, sadržanom u prvom zakonskom članu kojim se počinje regulisanje određenog ugovora. Tako je pojam ugovora o zakupu dat u par. 535. a pojam ugovora o službi u par. 611 BGB. Prema takvom modelu, za određenje kod mešovitih ugovora postojanja elemenata određenog tipa ugovora, pa i da li su pretežni ili sporedni, nije bitno da li se sve zakonske odredbe kojima se reguliše neki tip ugovora mogu primeniti i u slučaju određenog mešovitog ugovora, već je odlučujuće da li kod tog mešovitog ugovora postoje elementi koji čine suštinu „pojma“ određenog tipa ugovora. Ovakav pristup ne može se, međutim, primeniti na određenje pravne prirode ugovora o pružanju usluga fitnesa, već bi trebalo primeniti tzv. tipski metod. Prema tom metodu se pravna priroda mešovitog ugovora ceni uzimajući u obzir sve zakonske odredbe kojima je regulisan određeni tip ugovora, jer se samo tako može oceniti da li je u opšte moguća njihova primena u slučaju spora. Kad se tako pogledaju elementi ugovora o zakupu onako kako su regulisani odredbama Građanskog zakonika (BGB), videće se da se najveći broj odredbi Građanskog zakonika, i to najvažnije, uopšte ne mogu primeniti na tipične situacije

34 Videti, na primer, BGH, Urteil vom 08.02.2012, Az.: XII ZR 42/10; AG Brandenburg an der Havel, Urteil vom 15.10.2015, Az.: 34 C 5/15; AG Siegburg, Urteil vom 11.12.2014, Az.: 112 C 131/13, https://dejure.org/dienste/vernetzung/rechtsprechung?Gericht=AG\%20Siegburg\&Datum=18.03.2014\& Aktenzeichen $=112 \% 20 \mathrm{C} \% 20131 / 13$.

35 Patrick Schwefer, Die Wirksamkeit Allgemeiner Geschaeftsbedingungen in Fitenss-Vertraegen, Berlin, 2003, str. 27-28.

36 OLG Hamm, Urteil vom 10.10.1991 - 17 U 2/9, https://dejure.org/dienste/vernetzung/ rechtsprechung?Gericht=OLG\%20Hamm\&Datum=10.10.1991\&Aktenzeichen=17\%20U\%202/91 
koje postoje kod fitnes ugovora (ugovora o pružanju usluga fitnesa). To posebno važi za odredbe BGB kojima se reguliše odgovornost za nedostatke zakupljene stvari, održavanje i izmene na predmetu zakupa, predaja predmeta zakupa i $\mathrm{dr}^{37}$ Šta više, bilo bi suprotno pravoj volji ugovornih strana shvatiti fitnes ugovor kao ugovor sa dominantnim elementima ugovor o zakupu. To što se u opštim uslovima poslovanja, odnosno formularnim ugovorima fitnes centara većinom navodi samo obaveza fitnes centra da prepusti klijentu na korišćenje prostor i uređaje fitnes centra, apsolutno ne znači da se klijent želi odreći uslužnih činidbi. Shodno par. 133 i 157. BGB, izjave volje treba tumačiti tako kako bi ih primalac izjave morao razumeti sa stanovišta načela savesnosti i poštenja i uzimajući u obzir običaje u prometu. Zbog toga, ponudu fitnes centra, odnosno ugovor treba tumačiti tako da fitnes centar duguje sve uobičajene činidbe u odgovarajućoj poslovnoj branši.$^{38} \mathrm{U}$ te činidbe uvek spada i dužnost nadzora i davanja uputstava za korišćenje uređaja. ${ }^{39}$ Pojedinačne ugovorne obaveze su u tesnoj uzajamnoj vezi i ne mogu se posmatrati odvojeno. Imajući sve to u vidu, nije moguće ustanoviti opštevažeće pravilo koje propise treba primeniti na fitnes ugovor u njegovoj ukupnosti, već treba poći od „fleksibilne procene pojedinih pitanja" $u$ zavisnosti od okolnosti konkretnog slučaja. ${ }^{40}$

Konačno, u slučaju da su ugovorne strane zaključile tzv. ugovor o članstvu u fitnes centru (studiju)", u tom slučaju se, prema mišljenju nemačkih sudova, radi o tipski mešovitom ugovoru o prepuštanju upotrebe, ali koji ima elemente i ugovora o zakupu i ugovora o službi, pa se na njega odgovarajuće primenjuju odredbe i par. 535 i par. 611. BGB, kao i odredbe par. 314. BGB. ${ }^{41}$

Nešto drugačije stanovište imaju švajcarski pravnici. Ugovor o fitnesu je neimenovani ugovor koji ima elemente ugovora o zakupu i ugovora o nalogu Pravo pristupa i korišćenja prostora (garderobe, tuševa, toaleta, prostorija za trening i odmor) i uređaja fitnes centa ima zakupopravni karakter. Klijenti, međutim, ne stiču isključivo pravo korišćenja, već moraju prostor i uređaje da dele sa drugim klijentima (korisnicima). Pojedini korisnici imaju, dakle, samo sudržavinu. Zbog toga je bolje reći da je ugovor o fitnesu pravne prirode slične zakupu -ugovor sa zakupopravnim primesama (uticajem). Nasuprot tome, obaveze davanja instrukcija i saveta, vršenja nadzora i staranja o korisniku imaju elemente ugovora o nalogu. Zaključenjem ugovora o fitnesu se ne duguje određeni rezultat, već samo savetovanje

37 Fitnes ugovor je, po pravilu, usmeren na ,korišćenje opreme fitnes centra,,, što podrazumeva sve sportske uređaje (sprave i rekvizite) u njihovoj ukupnosti. Utoliko je nemoguće govoriti o ,zakupljenoj stvari“" u smislu par. 535 BGB. Ili, prema par. 537. st. 2. BGB, sve dok zakupodavac nije u mogućnosti da garantuje zakupcu upotrebu zakupljene stvari usled prepuštanja upotrebe trećem licu, zakupac nije dužan da plaća zakupninu. Kod tipičnog ugovora o zakupu, zakupodavac ispunjava svoju obavezu prepuštanja zakupcu upotrebe stvari tako što mu stavlja stvar na isključivo raspolaganje, i to po pravilu putem predaje. Kod fitnes ugovora tako nešto ne postoji. Klijent fitnes centra nije jedini kome je omogućeno da u isto vreme koristi iste sprave i rekvizite, čime su i rizici upotrebe razdeljeni drugačije nego kod klasičnog ugovora o zakupu. Martin Schwab, AGB-Recht, Heidelberg, 2008, str. 263.

38 Schwefer, op. cit., str. 28. i 29.

39 Ibid., str. 39.

40 Ibid., str. 57-58.

41 Prethodno navedena presuda AG Brandenburg, od 18. 04. 2016. 
prilikom upotrebe uređaja ili specijalno savetovanje na putu ka postizanju željenog cilja (npr. biti fit, pokretljiviji i sl.). Zbog toga ugovor o fitnesu nema elemente ugovora o delu. Status dela u smislu čl. 365. Zakona o obligacijama (OR) može da ima, na primer, izrada individualno prilagođenog plana treninga. Nasuprot tome, pribavljanje deindividualizovanog trening plana treba shvatiti kao kupovinu $\mathrm{u}$ skladu sa čl. 184. OR. To ne znači da u slučaju predaje korisniku standardnog trening plana ugovor o fitnesu dobija elemente ugovora o kupovinu, pošto se tu radi isključivo o sporednoj obavezi, kako bi klijent imao mogućnost da optimalno koristi infrastrukturu fitnes centra. Ovakvi elementi ugovora o fitnesu čine ga većinom neimenovanim ugovorom mešovite prirode (mixti iuris), a u određenim situacijama čak i neimenovanim ugovorom sui generis. ${ }^{42}$

Ovakva stanovišta nisu, međutim, prihvatljiva kada je u pitanju hrvatsko i srpsko pravo. Mi smatrao da ugovor o pružanju usluga fitnesa ispunjava sve uslove da bi se u, u osnovi i u najvećem broju slučajeva, smatrao podvrstom ugovora o delu. ${ }^{43} \mathrm{Tu}$ činjenicu ne potire ni okolnost da se zbog osobenosti ,posla“ na ovaj ugovor ne mogu baš u potpunosti primeniti sve zakonske odredbe koje se odnose na ugovor o delu. Ugovor o delu je, i u srpskom i u hrvatskom pravu, ugovor kojim se jedan ugovornik (poslenik) obavezuje da izvrši određeni posao za drugog ugovornika (naručioca), a ovaj se obavezuje da mu za to isplati određenu nagradu i da primi izvršeni posao. Posao koji se ovim ugovorom preduzima, po svojoj prirodi, je materijalni (faktički), a ne pravni posao. ${ }^{44}$ Sadržaj činidbe je činjenje, što znači da je reč o tzv. činidbi rada. Okvir mogućih poslova može biti veoma širok, jer obuhvata ne samo poslove zasnovane na nekoj telesnoj stvari već i one koji su „duhovne“ prirode. Ugovorom o delu poslenik se obavezuje da izvrši određeni posao, odnosno da preduzme određeni rad čiji rezultat će se ceniti s obzirom na prirodu obaveze, sadržinu i cilj ugovora koji su stranke htele postiće, s tim da izvršeni posao od strane poslenika ne mora uvek da dovede do ostvarivanja cilja ugovora. ${ }^{45}$ Za postojanje ugovora o delu nije bitno da li poslenik duguje rad ili rezultat rada, jer predmet ugovora je samo savestan i stručan rad po pravilima struke bez garancije da će dovesti do željenog rezultata. Ugovor o pružanju usluga fitnesa sadrži bitne elemente ugovora o delu: obavezu izvršenja određenog posla (organizovanje i omogućavanje fitnes treninga, vođenje treninga ili savetovanje od strane fitnes trenera - instruktora, nadzor nad ispravnošću

42 Arnold Rusch, Vertraege mit Fitnesstudios, https://docplayer.org/811867-Vertraege-mitfitnessstudios-inhaltsverzeichnis-1-terminologie-vertragsinhalt-und-parteien.html

43 Prema mišljenju pojedinih hrvatskih pravnika, ugovor o uslugama, po pravilu, nije ništa drugo do ugovor o delu, a samo izuzetno se neće moći podvesti isključivo pod pojam ugovora o delu jer će u određenoj meri sadržavati značajke i drugih imenovanih ugovora, zbog čega se takve ugovore treba smatrati mješovitim ugovorima koji imaju karakteristike dvaju ili više tipova posebnih ugovora. U određenim situacijama ugovore o uslugama će biti potrebno smatrati sui generis ugovorima sa svojom samostalnom pravnom fizionomijom zbog toga što im je sadržaj i kauza šira od one karakteristične za ugovor o djelu i zbog toga što ih se ne može promatrati kao puki zbroj karakteristika više imenovanih ugovora. Ivan Tot, Sto je to ugovor o uslugama (u hrvatskom pravu)?, u: Pravo i usluge / Mićović, Miodrag - Kragujevac : Kvark, Kraljevo, 2012, str. 55. $\mathrm{ZOO}$

44 Perović, Videti Slobodan Perović, Obligaciono pravo, Beograd, 1981, str. 711, str. 710; čl. 600.

45 Ibid., str. 711-712. 
uređaja za vežbanje i nad bezbednošću vežbača), na jednoj strani i obavezu isplate određene naknade (tzv. mesečna članarina) na drugoj strani. Kod u današnje vreme uobičajene tzv. „kupovine fitnes paketa“, „,itnes paket“ je nerazdvojna celini i obuhvata kako obezbeđenje i upravljanje opremom i prostorom za fitnes trening korisnika u cilju unapređenja fizičke pripremljenosti (što obuhvata i omogućavanje korišćenja) tako i planiranje, vođenje i obučavanje fitnes sportskim aktivnostima (odgovarajućem fizičkom vežbanju). Prosečni fitnes vežbač očekuje da se fitnes centar o njemu ,stara“ za vreme treninga. Drugačija situacija je, načelno, moguća samo u slučaju kada je jedina obaveza fitnes centra da omogući korisniku da vežba u prostoru i na opremi fitnes centra, uz eventualna uvodna uputstva (instrukcije), jer bi tada bili dominanti elementi ugovora o zakup, a sporedni ugovora o delu. Ali to je, po našem mišljenju, više teorijsko razmatranje nego praktično, jer u praksi više i ne postoje takvi fitnes centri. Šta više, u Republici Srbiji takav fitnes centar ne bi mogao ni da obavlja sportsku delatnost jer ne bi ispunjavao zakonom propisane uslove i obaveze ${ }^{46}$, a mogao bi biti izložen kako prekršajnoj tako i imovinskoj odgovornosti. ${ }^{47}$

Ukoliko bi se ugovor o pružanju usluga fitnesa smatrao podvrstom ugovora o zakupu, onda on u klasičnoj klasifikaciju ugovora prema njihovim specifičnim osobinama i funkcijama ne bi mogao ni smatrati ugovorom o uslugama. Prema podeli koju navode Klarić i Vedriš, ugovori obveznog prava dele se na ugovore o prijenosu stvari i prava, ugovore o uporabi i korištenju stvari, ugovore o uslugama i ugovor o ortaštvu. U ugovore o uslugama ubrajaju ugovor o djelu, ugovor o građenju, ugovor o ostavi, ugovor o uskladištenju, ugovor o nalogu, ugovor o punovlašću i ugovor o komisiji. ${ }^{48}$

Poseban problem predstavlja zaključenje ugovora putem tzv. VIP članarina, koje podrazumevaju čitav niz usluga pored samog korišćenja prostora i uređaja

46 Kako je pružanje usluga fitnesa, odnosno omogućavanje fitnes vežbanja u specijalizovanim sporskim objektima (fitnes centri, teretane) uslužna sporska delatnost, u skladu sa čl. 3. st. 1. tač. 2) Zakona o sportu, to i pružaoci tih usluga moraju da ispune određene uslove za obavljanje delatnosti propisane Zakonom o sportu i Pravilnikom o bližim uslovima za obavljanje sportskih delatnosti (,Sl. glasnik RS“, br. 63/2013). U skladu sa čl. 2. tog Pravilnika, fitnes centri koji imaju status privrednog društva mogu obavljati sportsku delatnost ako imaju obezbeđen odgovarajući prostor, odnosno objekat, odgovarajuću opremu, odgovarajuće sportske stručnjake u zavisnosti od vrste delatnosti, ako ispunjavaju uslove u pogledu bezbednosti za obavljanje delatnosti i ako imaju odgovarajuću unutrašnju organizaciju, odnosno službu, u skladu sa zakonom i pravilnikom. U te uslove spada i obaveza fitnes centra da obezbedi sigurnost korisnika sportskog objekta, na odgovarajući način i da ne dopusti korišćenje sportskog prostora, odnosno objekta ili opreme vežbaču koji nije dovoljno sposoban za izvođenje određene aktivnost.

47 Prema čl. 22. Zakona o sportu iz 2016. godine zabranjeno je sportistu izložiti sportskim aktivnostima koje mogu da ugroze ili pogoršaju njegovo zdravstveno stanje. Ako su u pitanju deca, ona se ne smeju izlagati ne samo sportskim aktivnostima nego ni bilo kakvim fizičkim vežbanjima koja mogu da ugroze ili pogoršaju njihovo zdravstveno stanje ili da negativno utiču na psihosocijalni i motorički razvoj. Kršenjem ovih zabrana čini se prekršaj za koji se organizaciji u oblasti sporta izriče novčana kazna u iznosu od 100.000 od 1.000.000 dinara, a preduzetniku novčana kazna u iznosu od 50.000 do 250.000 dinara (čl. 176. st. 1. tač. 5) i 6) i st. i 3. Zakona o sportu). Prema čl. 23. Zakona o sportu, sportista koji pretrpi štetu pri bavljenju sportskim aktivnostima ima pravo na naknadu štete u skladu sa opštim pravilima o odgovornosti za štetu, osim one štete koja je, u skladu sa sportskim pravilima, rezultat uobičajenih opasnosti i rizika bavljenja određenom sportskom aktivnošću.

48 Petar Klarić, Martin Vedriš, Građansko pravo, 12. izdanje, Zagreb, 2009, str. XXV-XXVIII. 
za vežbanje. Veliki fitnes centri danas nude svojim „klijentima“ paket različitih usluga (korišćenje usluga masera ili fizioterapeuta, korišćenje saune, solarijuma, slane sobe, obezbeđenje osvežavajućih napitaka i dr.). Zbog različitosti takvih „činidbi“, odnosno paketa usluga, ne može se na uopšten način odrediti pravna kvalifikacija ovakvog ugovora o korišćenju usluga fitnesa. On, u zavisnosti od okolnosti konkretnog slučaja, može imati i odredbe koje po svojoj prirodi spadaju u ugovor o prodaji, ugovor o zakupu, ugovor o delu, ugovor o nalogu. Najčešće će biti reč o ugovoru sa mešovitom pravnom prirodom, ali isprepletanost i raznovrsnost pravne prirode dugovanih činidbi može u konkretnom slučaju biti takva da se čak može govoriti o sui generis (atipičnom) ugovoru.

U sklopu razmatranja pravne prirode ugovora o pružanju usluga fitnesa treba razrešiti i pitanje da li je ovaj ugovor potrošački ugovor, odnosno, preciznije, potrošački ugovor o pružanju usluga. Razrešenje te dileme je od suštinskog značaja za različite probleme koji iskrsavaju u vezi zaključenja, sadržine i izvršenja ugovora. Pri odgovoru na ovo pitanje treba poći od prethodnih razmatranja o pravnoj prirodi ugovora i odredbi zakona kojima se reguliše zaštiti potrošača.

Zakon o zaštiti potrošača Republike Srbije ${ }^{49}$ definiše potrošački ugovor kao bilo koji ugovor zaključen između trgovca i potrošača (čl. 5. tač. 3). Ugovor o pružanju usluga jeste, pak, potrošački ugovor kojim se trgovac obavezuje da obavi određeni posao, kao što je izrada ili opravka određene stvari ili izvršenje određenog fizičkog ili intelektualnog rada, a potrošač se obavezuje da mu za to plati naknadu (čl. 3 . tač. 26). Status trgovca ima pravno ili fizičko lice koje nastupa na tržištu u sklopu svoje poslovne delatnosti ili u druge komercijalne svrhe, dok je potrošač fizičko lice koje na tržištu pribavlja usluge (ili robu) u svrhe koje nisu namenjene njegovoj poslovnoj ili drugoj komercijalnoj delatnosti (čl. 3. tač. 1) i 2.). Za potrošački ugovor je karakteristično da se zaključuje između dve nejednake strane, od kojih je jedna profesionalac a druga potrošač, što za posledicu ima i znatno ograničenje primene načela autonomije volje i slobode ugovaranja pri zaključenju ovih ugovora. ${ }^{50}$

U Republici Hrvatskoj potrošački ugovori podložni su posebnom režimu. Na njih se primenjuje odredba Zakona o obveznim odnosima ${ }^{51}$ i odredbe Zakona o zaštiti potrošača ${ }^{52}$. Prema članku 402. stavak 3. ZOO-a, potrošački ugovor je ugovor koji fizička osoba kao kupac sklapa izvan svoje gospodarske ili profesionalne djelatnosti s fizičkom ili pravnom osobom koja kao prodavatelj djeluje u skopu svoje gospodarske ili profesionalne djelatnosti. S druge strane, prema odredbi članka 39. ZZP-a reč je o ugovoru sklopljenom između trgovca i potrošača. Člankom 5. Zakona o zaštiti potrošača propisano je da je „potrošač“ svaka fizička osoba koja sklapa pravni posao ili djeluje na tržištu izvan svoje trgovačke, poslovne, obrtničke

\footnotetext{
49 „Sl. glasnik RS“, br. 73/2010.

50 Više videti, Miodrag Mićović, Zaštita prava potrošača, Kragujevac, 2009, str. 16-17.

„Narodne novine“", br. 35/05, 41/08, 125/11, 78/15, 29/18 - ZOO

„Narodne novine“, br. 41/14, 110/15, 14/19 - ZZP
} 
ili profesionalne djelatnosti, ${ }^{53}$ a "trgovac" je bilo koja osoba koja sklapa pravni posao ili djeluje na tržištu u okviru svoje trgovačke, poslovne, obrtničke ili profesionalne djelatnosti, uključujući i osobu koja nastupa u ime ili za račun trgovca (čl. 5. st. 1. tač. 15. i 26. ZZP).

Možemo, dakle zaključiti da ugovor o pružanju usluga fitnesa ispunjava i u Srbiji i u Hrvatskoj sve uslove da se smatra potrošačkim ugovorom o pružanju usluga. Organizacije koje obezbeđuju usluge za obavljanje fitnes sportskih aktivnosti, odnosno omogućavaju njihovo obavljanje u ogromnoj većini slučajeva imaju status trgovca jer se omogućavanje i vođenje vežbanja trećih lica obavlja kao osnovna poslovna delatnosti. ${ }^{54}$ Vežbač koji plati fitnes centru naknadu da bi trenirao u fitnes centra, jeste potrošač koji usluge fitnesa pribavlja „,u svrhe koji nisu namenjene njegovoj poslovnoj ili drugoj komercijalnoj delatnosti“. Isto je i u uporednom pravu. Tako je, na primer, austrijski Vrhovni sud u svojoj presudi 1 Ob 146/15z 8 od 22. 12. 2015. godine u kojoj je odlučivano o nedopuštenosti pojedinih odredbi formularnog ugovora o fitnesu konstatovao da tuženi ima status trgovca u smislu par. 1. Zakona o zaštiti potrošača - Konsumentenschutz Gesetz $(\mathrm{KSchG})$, a tužilac status potrošača. ${ }^{55}$

Čini nam se nepotrebnim naglašavati da i kod ugovora o pružanju usluga fitnesa postoje dve nejednake strane. Kao i svaku drugu uslugu, i uslugu koju duguje fitnes centar karakteriše neopipljivost, neodvojivost, heterogenost i nepostojanost. Reč je o profitnoj, potrošačkoj i radno zasnovanoj usluzi, usmerenoj na korisnika. ${ }^{56}$

Okolnost da je ugovor o pružanju usluga fitnesa potrošački ugovor povlači za sobom primenu na ovaj ugovor brojnih propisa o zaštiti potrošača, kako nacionalnih tako i onih koji su doneti na nivou Evropske unije. Tu posebno izdvajama Direktivu 93/13/EEZ o nepoštenim uslovima u potrošačkim ugovorima koja je u sudskoj praksi često primenjivana na brojne nepoštene odredbe u opštim uslovima poslovanja fitnes centara, odnosno formularnim ugovorima. Prema toj Direktivi, uslovi u potrošačkim ugovorima moraju udovoljavati određenim normama, a posebno biti u skladu s načelom dobre vere i ne smeu prouzrokovati znatniju neravnotežu u pravima i obavezama ugovornih strana na štetu potrošača. U praski je, međutim, često suprotno.

53 Prema tumačenju Suda Europske Unije potrošači su dobro informirane, razumne, pažljive i oprezne osobe. Nevenka Baran - Senka Orlić, Zaštita potrošača, Pravosudna akademija, Zagreb, 2019, str. 52

54 Izuzetak su fitnes sportska udruženja u odnosu na svoje sportiste članove. Međutim, u Srbiji i ove organizacije mogu izuzetno da se neposredno bave pružanjem usluga trećim licima u vidu privredne delatnosti, pod uslovima propisanim čl. 72. Zakona o sportu.

55 https://rdb.manz.at/document/ris.just.JJT_20151222_OGH0002_0010OB00146_15Z0000_000

56 O pojmu, obeležjima i klasifikaciji usluga videti: Nenad Đurđević, Miodrag Mićović, Zoran Vuković, Usluge u sportu, Kragujevac, 2019, 103-106. 


\section{LITERATURA}

1. Baran, N.; Orlić, S., Zaštita potrošača, Pravosudna akademija, Zagreb, 2019.

2. Batrakoulis, A., „European survey of fitness trends for 2020“, American College of Sports Medicine, Health \& Fitness Journal, November, 2019., p. 28-35.

3. Deklaracija o zajedničkim stavovima vezanim za politiku javnog zdravlja Svetske zdravstvene organizacije i Međunarodnog udruženja za sportsku medicinu (FIMS), doneta 1995. godine na Evropskom kongresu sportske medicine - Granada (Španija).

4. Ефремова, М. В.; Чкалова, О. В., Бошман, Т. К., Анализ российского рынка фитнес-услуг, ЭКОНОМИЧЕСКИЙ АНАЛИЗ: теория и практика, 21 (420) 2015., str. 25-35.

5. Fitness Boom in Europe Continues: Industry Grows Constantly, https://www.ispo. com/en/companies/fitness-boom-europe-continues-industry-grows-constantly.

6. Fitnesstraining - das Training der Fitness, http://www.fitness-trainingsplan, de/ fitnesstraining/.

7. Đurđević, N.; Mićović, M.; Vuković, Z., Usluge u sportu, Kragujevac, 2019. Klarić P.,

8. Jayme, E., „Allgemeine Geschaeftsbedingungen und internationales Privatrecht“", Zeitschrift fuer das gesamte Handelsrecht und Wirtschaftsrecht, Nr. 2, 1978., p. 105123.

9. Jankovec, I., Ugovori u privredi, Beograd, 1987.

10. Krtinić, G., Učestalost povreda kod intenzivno fizički aktivnih adolescenata, doktorska disertacija, Medicinski fakultet Univerziteta u Novom Sadu, 2014.

11. Mićović, M., Zaštita prava potrošača, Kragujevac, 2009.

12. Opći uslovi poslovanja OrlandoFit trgovačkog društva iz Zagreba, https://www. orlandofit.hr/o-nama/orlandofit-pravilnik/.

13. Out now: the European Health \& Fitness Market Report 2020, https://www. europeactive.eu/blog/out-now-european-health-fitness-market-report-2020.

14. Perović, S., Obligaciono pravo, Beograd, 1981.

15. Ramm, F., Der Sportstudiovertrag, https://www .rab-friedrich-ramm.de/beitrag19_ Sportstudiovertrag.html.

16. Rusch, A., Vertraege mit Fitnesstudios, https://docplayer.org/811867-Vertraege-mitfitnessstudios-inhaltsverzeichnis-1-terminologie-vertragsinhalt-und-parteien.html.

17. Schwefer, P., Die Wirksamkeit Allgemeiner Geschaeftsbedingungen in FitenssVertraegen, Berlin, 2003.

18. Schwab, M., AGB-Recht, Heidelberg, 2008.

19. Statut Hrvatskog bodybuilding saveza, https://www.hbbs.hr/media/Usklaeni_statut_ HBBS-a-2015.pdf.

20. Statut Saveza Srbije za bodibiling, fitnes, bodi fitnes i aerobik, http://bbss.rs/wpcontent/uploads/2019/02/statut.pdf.

21. Tot, I., „Što je to ugovor o uslugama (u hrvatskom pravu)?“, u: Pravo i usluge, Mićović, Miodrag, Kragujevac, 2012., str. 53-63. 
22. Urtei Bundesgerichtshof in Karlsruhe (BGH), vom 8. 02. 2012 - XII ZR 42/10, https:// dejure.org/dienste/vernetzung/rechtsprechung?Gericht=BGH\&Datum=02.08.2012\& Aktenzeichen=XII\%20ZR\%2042/10.

23. Urteil BGH, vom 07.03.2013, Az.: III ZR 231/12, https://dejure.org/dienste/ vernetzung/rechtsprechung?Gericht=BGH\&Datum=07.03.2013\&Aktenzeichen=I II\%20ZR\%20231\%2F12.

24. Urteil BGH, vom 08.02.2012, Az.: XII ZR 42/10, https://juris.bundesgerichtshof. de/cgi-bin/rechtsprechung/document.py?Gericht=bgh\&Art=en\&az=XII\%20ZR\%20 $42 / 10 \& n r=59681$.

25. Urteil BGH, vom 4. 05. 2016, KSII ZR 62/15, https://dejure.org/dienste/vernetzung/ rechtsprechung?Gericht=BGH\&Datum=04.05.2016\&Aktenzeichen=XII\%20ZR\%20 $62 / 15$.

26. Urteil Landesgericht Menhengladbah, vom 30.05.2003 - 2 S 22/03, https://www. kostenlose-urteile.de/LG-Moenchengladbach_2-S-2203_Erstvertragslaufzeit-von24-Monate-fuer-Fitnessstudio-bei-Moeglichkeit-zur-Wahl-der-Vertragslaufzeitzulaessig.news20442.htm.

27. Urteil Amtsgericht Brandenburg, Az: 31 C 204/15 vom 18. 04. 2016, https://www. ra-kotz.de/fitnessstudiovertrag-rechtsnatur.htm.

28. Urteil Amtsgericht Brandenburg an der Havel, vom 15.10.2015, Az.: 34 C 5/15 https://dejure.org/dienste/vernetzung/rechtsprechung?Gericht=AG\%20Brandenburg $\&$ Datum $=15.10 .2015 \&$ Aktenzeichen $=34 \% 20 \mathrm{C} \% 205 \% 2 \mathrm{~F} 15$.

29. Urteil Amtsgericht München, vom 13.10.2011, Aktenzeichen 213 C 22567/11, https:// dejure.org/dienste/vernetzung/rechtsprechung?Gericht=AG\%20M\%FCnchen\&Datu $\mathrm{m}=13.10 .2011$ \&Aktenzeichen $=213 \% 20 \mathrm{C} \% 2022567 / 11$.

30. Urteil Amtsgericht Hamburg, vom 05.02.1998, Aktenzeichen 20 b C 367/97, https:// dejure.org/dienste/vernetzung/rechtsprechung?Gericht=AG\%20Hamburg\&Datum $=0$ 5.02.1998\&Aktenzeichen=20b\%20C\%20367\%2F97.

31. Urteil Amtsgericht Münster, vom 8.06.2014, 271 C 30721/13, https://www.kostenloseurteile.de/AG-Muenster_271-C-3072113_Brille-vergessen-Ungelesener-Vertragmit-anderem-Inhalt-als-gedacht-kann-wirksam-angefochten-werden.news 19089. htm.

32. Urteil Amtsgericht München, vom 25. 10. 2012, 223 C 12655/12, https://www. kostenlose-urteile.de/AG-Muenchen_223-C-1265512_Bei-Vertragsabschluss-nachProbetraining-im-Fitnessstudio-besteht-kein-Widerrufsrecht.news15168.htm.

33. Urteil Amtsgericht Siegburg, vom 11.12.2014, Az.: 112 C 131/13, https://dejure.org/ dienste/vernetzung/rechtsprechung?Gericht=AG\%20Siegburg\&Datum=18.03.2014 \&Aktenzeichen $=112 \% 20 \mathrm{C} \% 20131 / 13$.

34. Urteil Arbeitsgericht Ulm, vom 14.11.2008, 3 Ca 244/08, www.jusmeum.de/ rechtsprechung/urteil/arbg_ulm/805bed22b9e5d6630f70edb45dd7e73a320a44d28e b8bac15122d61b49fb3ddf?page=1.

35. Urteil Landgericht Koblenz, vom 02.10.2007, Aktenzeichen 6 S 19/07, http://www. landesrecht.rlp.de/jportal/portal/t/7qe/page/bsrlpprod.psml?pid=Dokumentanzeige\& showdoccase $=1 \&$ doc. id=KORE241662007\&doc.part $=$ L. 
36. Urteil Oberlandsgericht Hamm, vom 10.10.1991, 17 U 2/9, https://dejure.org/dienste/ vernetzung/rechtsprechung?Gericht=OLG\%20Hamm\&Datum=10.10.1991\&Aktenz eichen $=17 \% 20 \mathrm{U} \% 202 / 91$.

37. Urteil Der Oberste Gerichtshof der Republik Österreich (OGH), vom 13. 03. 2014, 5 Ob 205/13b, https://rdb.manz.at/document/ris.just.JJT_20140313_OGH0002_005 0OB00205_13B0000_000.

38. Urteil OGH, vom 29.05.2012, 9 Ob 69/11d, https://www.ris.bka.gv.at/Dokument.wx e?Abfrage=Justiz\&Dokumentnummer=JJT_20120529_OGH0002_0090OB00069_ 11D0000_000.

39. Urteil $O G H$, vom 22. 12. 2015, 1 Ob 146/15z 8, https://rdb.manz.at/document/ris.just. JJT_20151222_OGH0002_0010OB00146_15Z0000_000.

40. Vedriš, M., Građansko pravo, 12. izdanje, Zagreb, 2009.

41. Zašto sa ekspanzijom fitnes industrije raste i broj gojaznih, https://opusteno.rs/ fitnes-trening-vezbe-f175/zasto-sa-ekspanzijom-fitnes-industrije-raste-i-brojgojaznih-t38776.htm. 


\section{CONTRACT ON PROVIDING FITNESS SERVICES}

Fitness is the most profitable sports activity in today's Europe with almost 65 million service consumers of numerous fitness centers and clubs in the year 2019. Fitness is a concept that implies well developed physical ability which is derived from physical readiness gathered through physical workout. Fitness center (studios, clubs) services are provided today solely on the contract on providing fitness services. It is a non-regulated contract which is called differently in various countries. In practice, this contract is made entirely in accordance with the standard contract terms adopted by fitness centers, or by making standard contracts prepared in advance by fitness centers. In his paper, the author considers the issues of conclusion and legal nature of this contract.

Key words: fitness, sport, contracts on fitness services, standard contract terms, consumer protection 